\title{
EVALUATION OF RECOMBINANT AVIAN INFLUENZA COMPARED TO INACTIVATED VACCINES TO INDUCE IMMUNE RESPONSE IN CHICKEN
}

\author{
Dalia, M. Omar ${ }^{1}$; Elham A. El-Ibiary ${ }^{1}$; K.A. El-Dougdoug ${ }^{2}$ and B.A. Othman ${ }^{2}$ \\ 1- The Central Laboratory for Evaluation of Veterinary Biologics (CLEVB), Cairo, Egypt \\ 2- Agric. Microbiology Dept. (Virology Lab.), Fac. of Agric., Ain Shams Univ., Cairo, Egypt
}

$[52]$

Keywords: Avian influenza, Recombinant vaccines, HI, HPAl, shedding, real-time RT-PCR

\section{ABSTRACT}

The present Avian Influenza epidemic in Egypt is consider one of the major problems facing the poultry field and caused by circulation of genetically and antigenetically diverse influenza H5N1 viruses. This problem is controlled by applying vaccination. The objective was to determine the Al H5 recombinant vaccines efficacy (rHVT-H5, rFP-AlH5 (Scotland and Ireland), k rND-Al and k rBuc$\mathrm{Al}+\mathrm{ND}$ ) against classical and variant field HPAI $\mathrm{H} 5 \mathrm{~N} 1$ viruses in comparison to the traditionally inactivated whole $\mathrm{Al}$ virus vaccines as $\mathrm{K} \mathrm{R} \mathrm{H5N1/}$ Egy, $k \mathrm{H} 5 \mathrm{~N} 2$ and $k$ combined $\mathrm{Al}+\mathrm{ND}$ vaccines. $\mathrm{A}$ single dose of the different types of vaccines either recombinant or inactivated whole virus vaccines was administered at different ages of chicken. Eight chicken groups were vaccinated with 8 vaccines and challenged after 4 weeks post vaccination to measure the protection \%. Fecal and tracheal swabs were taken after 2 day post challenge to detect viral shedding. It was found that, live rFP$\mathrm{Al}-\mathrm{H} 5$ of both Scotland and Ireland strains induced poor clinical protection with high level of virus shedding. While, inactivated rND-Al, live rHVT-H5 and inactivated rBuc-Al+ND vaccines induced high protection rates ranged from $86.7 \%$ to $93.3 \%$ against both classical and variant HPAI viruses with a decrease or suppression of viruses shedding. In a parallel way, the inactivated whole virus Al vaccines either K R H5N1 / Egy, k H5N2 or k $\mathrm{Al}+\mathrm{ND}$ induced a protection rates ranged from $85.7 \%$ to $100 \%$ with a high decrease in virus shedding levels. The data clearly indicate that inactivated whole $\mathrm{Al}$ virus and inactivated recombinant vaccines confers high levels of clinical protec- tion with suppression in viral shedding compared to that of live recombinant vaccines except rHVT$\mathrm{H} 5$ vaccine which induce a great level of protection and decrease in viral shedding in SPF chicken.

\section{INTRODUCTION}

Influenza A viruses are enveloped, negativestrand RNA with a segmented genome, a member of the Orthomyxoviridae family (Lupiani and Reddy 2009). They infect a large variety of animal and birds species (Munster and Fouchier 2009). On the basis of the antigenic properties of their two surface glycoproteins, hemagglutinin (HA) and neuraminidase (NA). Influenza $A$ viruses are classified in birds into $16 \mathrm{HA}(\mathrm{H} 1-16)$ and 9 NA (N1-9) subtypes, thus 144 possible combinations of which many could have been found in the field. (Robert et al 2013). The highly pathogenic avian influenza (HPAI) virus $\mathrm{H} 5 \mathrm{~N} 1$ causes multi-organ disease and death in poultry, resulting insignificant economic losses in the poultry industry. HPAI H5N1 also poses a major public health threat as it can be transmitted directly from infected poultry to humans with very high $(60 \%)$ mortality rate. It is widely accepted that continued human exposure to influenza viruses circulating in wild and domestic avian species poses a permanent pandemic threat (Yen and Webster 2009).

Vaccination has been considered a suitable and powerful tool to support Al eradication (Swayne 2003). Other vaccine strategies against HPAI H5N1 have been explored including live attenuated influenza vaccines (Mueller et al 2010), live vaccines based on heterologous viral vectors such as poxvirus (Kreijtz, et al 2007), adenovirus (Gao, et al 2006), turkey herpesvirus (HVT) (Gardin et al 2016), baculovirus (Wu et al 2009) and Newcastle disease virus (DiNapoli et al 2010), 
and DNA vaccination (Rao et al 2008). While these different strategies often showed promising results, their applicability ultimately will depend on various important issues including safety, efficacy, production and costs (Ellebedy and Webby 2009). An influenza vaccine based on recombinant purified HA could offer the following advantages: I) The HA antigen can be produced using safe, quality-controlled and scalable conditions. II) There will be no need for virus cultivation, thus avoiding the necessity a) to obtain viruses that replicate efficiently in eggs or cell culture, b) to use biocontainment facilities and $c$ ) to inactivate the virus using procedures that may affect antigenicity and raise safety concerns. III) There combinant HA protein can be highly purified thereby limiting adverse reactions caused e. g. by the presence of egg contaminants. IV) Immunization with recombinant $\mathrm{HA}$ will allow the serological differentiation of naturally infected from vaccinated animals/flocks (the so-called DIVA principle; Van Oirschot, 2001). V) Recombinant $H A$ vaccines are manufactured with a relatively short lead time, allowing an accelerated response to emerging influenza strains. Moreover, the disadvantages of some live recombinant vaccines include the risk of generating revertants and allow spread of genetically modified organisms in the environment (Toro et al
2008). In Egypt, there are two conventional types of $\mathrm{Al}$ vaccines, the whole virus inactivated $\mathrm{Al}$ vaccines either reassortant H5N1 or LPAI H5N2 vaccines and recombinant live and dead vectored vaccines express Al-HA genes. This study aimed to determine the efficacy of the different types of recombinant $\mathrm{Al}$ vaccines and comparing the immune responses of the vaccines with that against inactivated $\mathrm{Al}$ vaccines and their ability to challenge the endemic Egyptian HPAl viruses.

\section{MATERIALS AND METHODS}

The experiments were done at Central Laboratory for Evaluation of Veterinary Biologics (CLEVB).

\section{Animals}

Eight groups of healthy chickens specificpathogen-free (SPF) from Khom Oshem farm, El Fayoum, as one day and 4 week old. Each group of birds was housed separately in positive pressured isolators till used.

Recombinant \& Inactivated Vaccines: were used in this study were tested in Table (1).

Table 1. Tested vaccine types, strains, routes and doses.

\begin{tabular}{|c|c|c|}
\hline Vaccine types & Al Strains & Route \& dose \\
\hline $\begin{array}{l}\text { Live recombinant fowl pox-Al } \\
\text { ( } \mathrm{FP}+\mathrm{Al}-\mathrm{H} 5 \text { (Scotland) }\end{array}$ & $\mathrm{A} /$ chicken/Scotland/59 & $\begin{array}{l}\text { one day old chicks } \\
\text { subcutanoesly } 0.2 \mathrm{ml} / \mathrm{bird} \text {. }\end{array}$ \\
\hline $\begin{array}{l}\text { Live recombinant fowl pox-Al } \\
(\mathrm{rFP}+\mathrm{Al}-\mathrm{H} 5 \text { (Ireland) }\end{array}$ & $\mathrm{A} /$ chicken/Irland/83 & $\begin{array}{l}\text { one day old chicks subcu- } \\
\text { tanoesly } 0.2 \mathrm{ml} / \text { bird }\end{array}$ \\
\hline $\begin{array}{l}\text { Recombinant turkey herpesvirus-AI (rHVT- } \\
\text { H5) }\end{array}$ & A/swan/Hungary/4999/2006 & $\begin{array}{l}\text { one day old chicks subcu- } \\
\text { tanoesly } 0.2 \mathrm{ml} / \mathrm{bird} \text {. }\end{array}$ \\
\hline $\begin{array}{l}\text { Killed recombinant ND-Al } \\
\text { (k rND-AI) }\end{array}$ & $\begin{array}{l}\text { A/chicken/Egypt/1063/2010 } \\
\text { LaSota }\end{array}$ & $\begin{array}{l}4 \text { weeks old chicken sub- } \\
\text { cutanoesly } 0.5 \mathrm{ml} / \text { bird. }\end{array}$ \\
\hline $\begin{array}{l}\text { Killed recombinant Baculo } \mathrm{Al}+\mathrm{ND} \text { (k rBuc- } \\
\mathrm{Al}+\mathrm{ND} \text { ) }\end{array}$ & $\begin{array}{l}\text { A/duck/china/E319-2/2003 } \\
\text { LaSota }\end{array}$ & $\begin{array}{l}4 \text { weeks old chicken sub- } \\
\text { cutanoesly } 0.5 \mathrm{ml} / \text { bird. }\end{array}$ \\
\hline $\begin{array}{l}\text { Killed Reassortant H5N1 } \\
\text { (K R H5N1/Egy) }\end{array}$ & A/chicken/Egypt/A-18-H/09 & $\begin{array}{l}4 \text { weeks old chicken sub- } \\
\text { cutanoesly } 0.3 \mathrm{ml} / \text { bird. }\end{array}$ \\
\hline Killed H5N2 Al (k H5N2) & $\begin{array}{l}\text { A/Chicken/Mexico/ } \\
\text { 232/94/CPA }\end{array}$ & $\begin{array}{l}4 \text { weeks old chicken sub- } \\
\text { cutanoesly } 0.5 \mathrm{ml} / \text { bird. }\end{array}$ \\
\hline $\begin{array}{l}\text { Combined Killed Al H5N1 and Newcastle } \\
\text { vaccine (K Al+ND) }\end{array}$ & $\begin{array}{l}\text { A/Chicken/Mexico/232/94/C } \\
\text { PA LaSota }\end{array}$ & $\begin{array}{l}4 \text { weeks old chicken sub- } \\
\text { cutanoesly } 0.5 \mathrm{ml} / \mathrm{bird} \text {. }\end{array}$ \\
\hline
\end{tabular}



induce immune response in chicken

\section{Antigen and antisera}

The homologous Al antigens and antisera were obtained from the vaccine manufactures corresponding the vaccine type. While, ND Ag and antisera were obtained from GD, Netherland. The antigens were used for serological Heamagglutination Inhibition test.

\section{Culture media for swabs processing}

Tryptose phosphate broth code No. 0060-01 Difco laboratories, Detriot, Michigan, USA. It was used to cultivation of tracheal and cloacal swabs for determine of viral shedding.

\section{Challenge virus:}

- Variant Al strain: Local HPAI field isolate was isolated and identified by National Laboratory for Veterinary Quality Control on Poultry Production, Animal Health Research Institute, (NLQP) as A/Ch/Egypt/1709-6/2008 (H5N1). Its titer was $10^{10} \mathrm{EID}_{50} / \mathrm{ml}$. the challenge dose was adjusted to be $10^{5}$ EID $_{50} / 0.1 \mathrm{ml}$ per bird and administrated intranasal.

- Classical Al strain: Local HPAI field isolate was obtained from Inactivated Viral Poultry Vaccines Department at Central Laboratory for Evaluation of Veterinary Biologics (CLEVB) and identified by NLQP as A/Ch/Egypt/Qal-3/2016 (H5N1). Its titer was $10^{11.5} \mathrm{EID}_{50} / \mathrm{ml}$. the challenge dose was adjusted to be $10^{7.5}$ EID $50 / 0.1 \mathrm{ml}$ per bird and administrated intranasal.

\section{Potency test}

50 SPF healthy chickens, one day and 4 week old are vaccinated S/C with one dose of each tested live recombinant and inactivated either recombinant or whole virus Al vaccines. Blood samples were drawn weekly post vaccination for serological analysis of $\mathrm{Al}$ immune response using heamagglutinin inhibition $(\mathrm{HI})$ test. 30 birds out of each vaccinated and 20 birds of control groups were challenged with intranasaly both $10^{5}$ EID $_{50}$ challenge dose of variant HPAI and $10^{7.5}$ EID $_{50}$ challenge dose of classical HPAl challenge viruses in $0.1 \mathrm{ml} /$ bird after 4 week old vaccination. The mortality and morbidity rates were recorded for each group during observation period (10 days) to measure the protection \%.The assessment of viral shedding of HPAl challenge virus was performed through collection of orophayngeal swabs in tryptose media with antibiotic mixture on 2 days post challenge either from the vaccinated and control groups using virus reisolation in embryo chicken eggs (ECE) and rRT-PCR methods (OIE, 2017).

\section{Heamagglutinin inhibition assay $(\mathrm{HI})$}

The Heamagglutinin inhibition $(\mathrm{HI})$ test was performed as described previously (OIE, 2017) using $4 \mathrm{HA}$ units of the homologous $\mathrm{Al}$ antigen corresponding each vaccinal strains. The $\mathrm{HI}$ titers were determined as the reciprocal of the highest serum dilution in which inhibition of hemeagglutination was observed.

\section{Determination of virus shedding}

It was done according to Pushko et al (2017) in which the collected swabs after challenge on tryptose media were left at room temperature for 30 minutes then centrifuged at $3000 \times$ g for 10 minutes. The supernatant of each sample were diluted ( 2 fold) and each dilute was inoculated into five 9-day old- SPF ECE. The infected embryos were incubated at $37^{\circ} \mathrm{C}$ for 5 days and examined daily. Alantoic fluid from each dead and live embryos were tested at the end of incubation period using slide Heamagglutinin (HA) test (Swayne et al 1998).

\section{Quantitative real-time RT-PCR (rRT-PCR)}

For detection of viral shedding, orophayngeal swabs were processed for rRT-PCR according to Das et al (2009). The viral RNA was extracted using RNA extraction kit (Qi Aamp viral RNA mini kit, Qiagen \# 52904). Then the rRT-PCR was conducted according to the rRT-PCR kit instruction (Quanti Tech prabe RT-PCR, Qiagen \#204443) using specific primer sets and probes as in Table (2).

Table 2. Oligonucleotide sequences of primer and probes for detection virus by rRT-PCR

\begin{tabular}{|c|c|c|l|}
\hline Virus & \multicolumn{3}{|c|}{ Sequences } \\
\hline \multirow{4}{*}{ Al $(\mathrm{Hb})$} & $\begin{array}{c}\text { Pri- } \\
\text { mers }\end{array}$ & H5LHI & $\begin{array}{l}\text { ACATATGAC- } \\
\text { TACCCACARTATTCAG }\end{array}$ \\
\cline { 2 - 4 } & Probe & H5PRO & $\begin{array}{l}\text { AGACCAGCTAY- } \\
\text { CATGATTGC }\end{array}$ \\
\cline { 2 - 4 } & $\begin{array}{l}\text { (FAM)TCWACAGTGGCGAGT } \\
\text { TCCCTAGCA(TAMRA) }\end{array}$ \\
\hline
\end{tabular}


The RT-PCR reaction scheme was on cycle at $50^{\circ} \mathrm{C}$ for $30 \mathrm{~min}$, on cycle at $45^{\circ} \mathrm{C}$ for $15 \mathrm{~min}$ and 40 cycles $\left(95^{\circ} \mathrm{C}\right.$ for 10 seconds, $60^{\circ} \mathrm{C}$ for $1 \mathrm{~min}$ and $72^{\circ} \mathrm{C}$ for 10 seconds).

\section{Experimental design}

SPF chickens (430) were used for evaluation the efficacy of different recombinant and inactivated either recombinant or whole virus avian influenza vaccines. The chickens were divided into $8 \mathrm{ex}$ perimental groups (50 birds /each), corresponding to each tested vaccine. Each group was divided into 3 subgroups, one had 20 birds for serological test and the $2^{\text {nd }}, 3^{\text {rd }}$ had 15 chickens/ each for challenge against classical (15 birds) and variant (15 birds) HPAl viruses. Also, the control nonvaccinated group (30 birds) was divided into 3 subgroups (10/each), the $1^{\text {st }}$ and $2^{\text {nd }}$ subgroup in challenged with classical and variant HPAI viruses respectively, while the $3^{\text {rd }}$ subgroup kept as control unvaccinated and unchallenged.

\section{RESULTS}

\section{Antibody response:}

All chicken groups vaccinated with inactivated Al vaccines either whole virus or recombinant showed high antibody titer at 4 weeks post vaccination up to $7.1,7,8,8,7.6$ for $\mathrm{k} r N D-A l, k$ baculo $\mathrm{Al}+\mathrm{ND}, \mathrm{k} \mathrm{R}$ H5N1/Egy, $\mathrm{k} \mathrm{H} 5 \mathrm{~N} 2$ and $k$ $\mathrm{Al}+\mathrm{ND}$ vaccines respectively. $\mathrm{HI}$ titers of chicken vaccinated with rHVT-H5 vaccines were much lower and did not reach to the basic level (7 log2) for vaccine release as shown in table (3). The $\mathrm{HI}$ titers increased for all groups until 10 WPV while control group show zero $\mathrm{HI}$ titer allover the weeks post vaccination.

Table 3. The mean of $\mathrm{HI}$ antibody titer in sera of chicken vaccinated with different types of $\mathrm{Al}$ vaccines using homologous antigens

\begin{tabular}{|c|c|c|c|c|c|c|c|c|c|c|c|}
\hline \multirow{2}{*}{ Vaccine type } & \multirow{2}{*}{$\begin{array}{l}\text { No. of } \\
\text { Sample }\end{array}$} & \multicolumn{10}{|c|}{ Weeks post vaccination } \\
\hline & & 1 & 2 & 3 & 4 & 5 & 6 & 7 & 8 & 9 & 10 \\
\hline rHVT-H5 & 10 & 2 & 3.6 & 4.5 & 5.6 & 6.1 & 6.4 & 7.1 & 7.3 & 7.5 & 7.8 \\
\hline k rND-Al & 10 & 2.1 & 3.5 & 6.0 & 7.1 & 7.5 & 7.8 & 8.0 & 8.0 & 7.5 & 7.5 \\
\hline k rBuc-Al+ND & 10 & 2.5 & 3.8 & 6.4 & 7.0 & 7.8 & 8.0 & 8.1 & 8.1 & 8.3 & 8.0 \\
\hline k R H5N1 / Egy & 10 & 3.0 & 4.8 & 7.1 & 8 & 8 & 8 & 8 & 7.9 & 7.9 & 7.8 \\
\hline k H5N2 & 10 & 3.7 & 4.8 & 6.5 & 8 & 9.2 & 9.8 & 10.3 & 10.4 & 10.4 & 10.5 \\
\hline k Al+ND & 10 & 2.5 & 4.3 & 6.4 & 7.6 & 8.5 & 8.7 & 8.7 & 8.9 & 9.0 & 9.0 \\
\hline Control & 10 & 0 & 0 & 0 & 0 & 0 & 0 & 0 & 0 & 0 & 0 \\
\hline
\end{tabular}

\section{Vaccine efficacy}

\section{a) Protection \%}

The protection $\%$ of the tested Al vaccines was illustrated in Tables (4 \& 5). The protection \% of birds vaccinated with live rHVT-H5, rFP-Al-H5 (Scotland) and rFP-Al-H5 (Ireland) and challenged with local HPAI 2.2.1.1. Challenge virus were $93.3 \%, 20 \%$ and $33.3 \%$ respectively (Table 4 ). Moreover, The protection \% of groups vaccinated with inactivated recombinant $\mathrm{k}$ rND-Al and $\mathrm{k}$ rBuc$\mathrm{Al}+\mathrm{ND}$ were $86.7 \%$ and $93.3 \%$, while the protection $\%$ for the chicken groups vaccinated with the inactivated whole Al virus either K R H5N1 / Egy, K $\mathrm{H} 5 \mathrm{~N} 2$ and $\mathrm{K} \mathrm{Al}+\mathrm{ND}$ were $100 \%, 92.9 \%$ and $85.7 \%$ respectively. On the other hand, results of protection \% of the vaccinated and control group, challenged with local HPAI 2.2.1.2 challenge virus were showed in table (5). The protection \% of live rHVT-H5, rFP-Al-H5 (Scotland) and rFP-Al-H5 (Ireland) were $90 \%, 26.7 \%$ and $40 \%$ respectively, while the inactivated recombinant $\mathrm{k} r \mathrm{rD}-\mathrm{Al}$ and $\mathrm{k}$ rBuc-Al+ND protect the chicken against challenge virus with a ratio of $86.7 \%$ and $93.3 \%$. Also, the chicken vaccinated with inactivated $k$ R H5N1 /Egy, k H5N2 and k Al+ND were protected with a percentage reach to $100 \%, 93.3 \%$ and $86.7 \%$ respectively. 

induce immune response in chicken

Table 4. The protection \% of different types Al vaccines against the challenge with variant strain of Egyptian HPAI H5N1 virus.

\begin{tabular}{|c|c|c|c|c|c|c|c|c|c|c|c|c|c|}
\hline \multirow{3}{*}{ Vaccine type } & \multirow{3}{*}{$\begin{array}{l}\text { No. of birds } \\
\text { /challenge }\end{array}$} & \multicolumn{10}{|c|}{ Challenge (4 weeks post vaccination) } & \multirow{3}{*}{ Total deaths } & \multirow{3}{*}{ Protection \% } \\
\hline & & \multicolumn{10}{|c|}{ Days post challenge (DPC) } & & \\
\hline & & 1 & 2 & 3 & 4 & 5 & 6 & 7 & 8 & 9 & 10 & & \\
\hline rFP-AI-H5 (Scotland) & 15 & & & 7 & 4 & 1 & & & & & & $12 / 15$ & $20 \%$ \\
\hline rFP-AI-H5 (Ireland) & 15 & & & 5 & 4 & 1 & & & & & & $10 / 15$ & $33.3 \%$ \\
\hline rHVT-H5 & 15 & & & & 1 & & & & & & & $1 / 15$ & $93.3 \%$ \\
\hline k rND-Al & 15 & & & 1 & & 1 & & & & & & $2 / 15$ & $86.7 \%$ \\
\hline k rBuc-Al+ND & 15 & & & & & 1 & & & & & & $1 / 15$ & $93.3 \%$ \\
\hline K R H5N1 / Egy & 15 & & & & & & & & & & & $0 / 15$ & $100 \%$ \\
\hline K H5N2 & 15 & 1 & & & 1 & & & & & & & $1 / 14$ & $92.9 \%$ \\
\hline $\mathrm{KAl}+\mathrm{ND}$ & 15 & 1 & & & 1 & 1 & & & & & & $2 / 14$ & $85.7 \%$ \\
\hline Control & 10 & & 1 & 9 & & & & & & & & $10 / 10$ & 0 \\
\hline
\end{tabular}

Table 5. The protection \% of different types Al vaccines against the challenge with classical strain of Egyptian HPAI H5N1 virus.

\begin{tabular}{|c|c|c|c|c|c|c|c|c|c|c|c|c|c|}
\hline \multirow{3}{*}{ Vaccine type } & \multirow{3}{*}{$\begin{array}{l}\text { No. of birds } \\
\text { /challenge }\end{array}$} & \multicolumn{10}{|c|}{ Challenge (4 weeks post vaccination) } & \multirow{3}{*}{ Total deaths } & \multirow{3}{*}{ Protection \% } \\
\hline & & \multicolumn{10}{|c|}{ Days post challenge (DPC) } & & \\
\hline & & 1 & 2 & 3 & 4 & 5 & 6 & 7 & 8 & 9 & 10 & & \\
\hline rFP-AI-H5 (Scotland) & 15 & & & 6 & 4 & 1 & & & & & & $11 / 15$ & $26.7 \%$ \\
\hline rFP-AI-H5 (Ireland) & 15 & & & 5 & 3 & 1 & & & & & & $9 / 15$ & $40 \%$ \\
\hline rHVT-H5 & 15 & & & & 1 & & & & & & & $1 / 15$ & $93.3 \%$ \\
\hline k rND-Al & 15 & & & & & 1 & 1 & & & & & $2 / 15$ & $86.7 \%$ \\
\hline k rBuc-Al+ND & 15 & & & & & & 1 & & & & & $1 / 15$ & $93.3 \%$ \\
\hline k R H5N1 / Egy & 15 & & & & & & & & & & & $0 / 15$ & $100 \%$ \\
\hline k H5N2 & 15 & & & & 1 & & & & & & & $1 / 15$ & $93.3 \%$ \\
\hline $\mathrm{k} \mathrm{Al}+\mathrm{ND}$ & 15 & & & & 2 & & & & & & & $2 / 15$ & $86.7 \%$ \\
\hline Control & 10 & & 1 & 8 & 1 & & & & & & & $10 / 10$ & 0 \\
\hline
\end{tabular}

\section{b) Determination of virus shedding}

\section{Virus reisolation}

The virus shedding was determined using virus reisolation in SPF ECE from tracheal and fecal swabs from both vaccinated and control groups on day 2 post challenge. All tracheal and cloacal swabs collected from birds in the control groups challenged with both local variant 2.2.1.1 and classical 2.2.1.2 HPAl virus were positive for virus reisolation as shown in Tables (6 \& 7). Results for vaccinated birds challenged with the variant 2.2.1.1 HPAl virus are shown in table (6). It was observed that in case of live rFP-Al-H5 (Scotland) and (Ireland) there was very low level of challenge virus reduction ranged from $10^{0.3}-10^{0.7}$ and 11 $13 / 15$ cloacal and tracheal swabs were positive for virus reisolation, but the virus shedding of $k$ rND-Al and $\mathrm{k}$ rBuc-Al+ND was reduced with a level ranged
3-3.2 respectively, while the rHVT-H5 vaccine evoked a reduction in the challenge virus dose shed from respiratory tract equal $10^{3.4}$ and no viral shedding from digestive tract. Also, it was showed that there was reduction in variant challenge virus replication either 2.5, 3 and 3.5 EID $_{50}$ from tracheal swabs of chicken vaccinated with inactivated whole virus either $\mathrm{k} \mathrm{Al+ND,} \mathrm{k} \mathrm{R} \mathrm{H5N1/Egy} \mathrm{and} \mathrm{k}$ H5N2 vaccines respectively, in addition, to a very low number of cloacal swabs were positive for virus reisolation (1/15, 2/15 and 0/15). The results of virus shedding from the vaccinated birds challenged with classical 2.2.1.2 HPAl virus were cleared in Table (7). It was observed that there was a reduction in the viral shedding from tracheal swabs with levels of $0.5,0.7,4.8,3.5,6,4.5,4$ \& 6 $\mathrm{EID}_{50}$ for groups vaccinated with rHVT-H5, rFP-AlH5 (Scotland), rFP-Al-H5 (Ireland), k rND-Al and k rBuc-Al+ND, k R H5N1 /Egy, k H5N2 and k Al+ND vaccines respectively. In addition to there were 
very high levels of viral shedding from the fecal swabs of chicken vaccinated with rFP-Al-H5 of both types were $13 / 15$ bird were positive; while the viral shedding from cloaca of the bird vaccinated with other type of $\mathrm{Al}$ vaccines ranged from $0 / 15$ (in case of rHVT-H5, k R H5N1 /Egy and k H5N2) to $1 / 15,1 / 15 \& 3 / 15$ in case of $k$ rBuc-Al+ND, $k$ $\mathrm{Al}+\mathrm{ND}$ and $\mathrm{k} r \mathrm{ND}-\mathrm{Al}$ vaccines, respectively.

\section{2 rRT-PCR}

All the tracheal \& fecal swabs taken from the vaccinated \& control groups after challenge with the variant HPAI virus were tested for viral shedding using rRT-PCR as shown in Tables (6 \& 7). It was cleared that the chicken vaccinated with two kinds of rFP-Al vaccines shed a high level (1.1 \& $1.2 \times 10^{6}$ ) of challenge virus with low CT (26) as the control groups $\left(2.7 \times 10^{6}\right)$ either from respiratory and digestive tracts. The results clearly showed that birds group vaccinated $\mathrm{k} R \mathrm{H} 5 \mathrm{~N} 1$ /Egy vaccine shed a relatively lower amount of challenge virus $\left(1.1 \times 10^{4}\right)$ from the respiratory tract while their fecal swabs were negative. The number of virus copies shed by chicken groups vaccinated with rHVT-H5, $\mathrm{k} \mathrm{Al}+\mathrm{ND}$ \& $\mathrm{k}$ rBuc-Al+ND vaccines were $2.794 \mathrm{X}$ $10^{4}, 4.001 \times 10^{4} \& 1.694 \times 10^{4}$ respectively, and their fecal swabs were negative. Moreover, the amount of virus shed by both groups vaccinated with $k$ rND-Al \& $\mathrm{k} \mathrm{Al}+\mathrm{ND}$ were $4.338 \times 10^{5}$ \& $1.122 \times 10^{5}$ with no viral shedding from their cloaca. On the other hand, the viral shedding from the vaccinated birds challenged with classical strain was showed in Table (7) with the same manner there was high level of viral shedding from the group vaccinated with the rFP-AI-H5 of both types $\left(1.3 \times 10^{6}\right)$ and showed positive fecal swabs in parallel to the control group which show positive fecal swabs and high titer of viral shedding from tracheal swabs $\left(1.6 \times 10^{6}\right)$. moreover, the viral shedding from tracheal swabs showed increased level from $1.2 \times 10^{4}$, $1.58 \times 10^{4}, 2.6 \times 10^{4}, 3.9 \times 10^{4}, 4 \times 10^{5} \& 1.1 \times 10^{5}$ in case of $k \mathrm{R} \mathrm{H5N1/Egy,} \mathrm{k} \mathrm{rBuc-Al+ND,} \mathrm{rHVT-H5,} \mathrm{k}$ $\mathrm{Al}+\mathrm{ND}, \mathrm{k} r \mathrm{ND}-\mathrm{Al} \& \mathrm{k} \mathrm{Al+ND}$ vaccines respectively with a negative results in their fecal swabs as detected with rRT-PCR.

Table 6. Viral shedding from vaccinated chicken with different Al vaccine types and challenged with variant strain (2008) of Egyptian HPAI H5N1 virus.

\begin{tabular}{|c|c|c|c|c|c|c|c|c|}
\hline \multirow{4}{*}{ vaccine } & \multirow{4}{*}{ 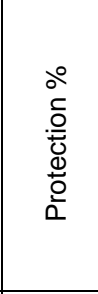 } & \multicolumn{7}{|c|}{ Challenge (4 WPV) } \\
\hline & & \multicolumn{4}{|c|}{$\begin{array}{c}\text { Viral shedding } 2 \text { days post challenge (DPC) by } \\
\text { ECE }\end{array}$} & \multicolumn{3}{|c|}{ Viral shedding 2 DPC by r-RT-PCR } \\
\hline & & \multicolumn{3}{|c|}{ Tracheal swab } & \multirow[b]{2}{*}{$\begin{array}{c}\text { Fecal swab } \\
(+ \text { ve/total })\end{array}$} & \multicolumn{2}{|c|}{ Tracheal swab } & \multirow[b]{2}{*}{$\begin{array}{c}\text { Fecal swab } \\
(+ \text { ve/total })\end{array}$} \\
\hline & & $\begin{array}{c}\text { Sample } \\
(+ \text { ve/total })\end{array}$ & $\begin{array}{l}\text { Virus titer } \\
\mathrm{EID}_{50} / \log _{10}\end{array}$ & $\begin{array}{c}\text { Viral reduc- } \\
\text { tion } \\
\log _{10} \\
\end{array}$ & & CT & $\begin{array}{c}\text { Conc. } \\
\text { (copies/140ml) }\end{array}$ & \\
\hline rFP-Al-H5 (Scotland) & $20 \%$ & $13 / 15$ & 5.2 & 0.3 & $13 / 15$ & 26.84 & $1.1 \times 10^{6}$ & +ve \\
\hline rFP-AI-H5 (Ireland) & $33.3 \%$ & $13 / 15$ & 4.8 & 0.7 & $11 / 15$ & 26.94 & $1.2 \times 10^{6}$ & $+v e$ \\
\hline rHVT-H5 & $93.3 \%$ & $1 / 15$ & 2.2 & 3.3 & $0 / 15$ & 32.63 & $2.794 \times 10^{4}$ & $-v e$ \\
\hline k rND-Al & $86.7 \%$ & $5 / 15$ & 3.3 & 2.2 & $2 / 15$ & 28.56 & $4.338 \times 10^{5}$ & -ve \\
\hline k rBuc-Al+ND & $93.3 \%$ & $3 / 15$ & 2.5 & 3 & $0 / 15$ & 32.94 & $1.694 \times 10^{4}$ & $-v e$ \\
\hline k R H5N1 / Egy & $100 \%$ & $1 / 15$ & 2 & 3.5 & $0 / 15$ & 33.44 & $1.108 \times 10^{4}$ & $-v e$ \\
\hline k H5N2 & $92.9 \%$ & $2 / 15$ & 2.5 & 3 & $1 / 15$ & 32.02 & $4.001 \times 10^{4}$ & -ve \\
\hline $\mathrm{k} \mathrm{Al}+\mathrm{ND}$ & $85.7 \%$ & $4 / 15$ & 3 & 2.5 & $2 / 15$ & 30.73 & $1.122 \times 10^{5}$ & -ve \\
\hline Control & 0 & $5 / 5$ & 5.5 & 0 & $5 / 5$ & 25.63 & $2.7 \times 10^{6}$ & + ve \\
\hline
\end{tabular}



induce immune response in chicken

Table 7. Viral shedding from vaccinated chicken with different Al vaccine types and challenged with classical strain (2016) of Egyptian HPAI H5N1 virus.

\begin{tabular}{|c|c|c|c|c|c|c|c|c|}
\hline \multirow{4}{*}{ Vaccine } & \multirow{4}{*}{ 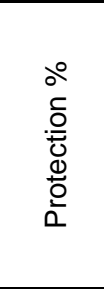 } & \multicolumn{7}{|c|}{ Challenge (4 WPV) } \\
\hline & & \multicolumn{4}{|c|}{$\begin{array}{c}\text { Viral shedding } 2 \text { days post challenge (DPC) } \\
\text { by ECE }\end{array}$} & \multicolumn{3}{|c|}{$\begin{array}{c}\text { Viral shedding } 2 \text { DPC by r-RT- } \\
\text { PCR }\end{array}$} \\
\hline & & \multicolumn{3}{|c|}{ Tracheal swab } & \multirow[b]{2}{*}{$\begin{array}{l}\text { Fecal swab } \\
\text { (+ve/total) }\end{array}$} & \multicolumn{2}{|c|}{ Tracheal swab } & \multirow[b]{2}{*}{$\begin{array}{l}\text { Fecal swab } \\
\text { (+ve/total) }\end{array}$} \\
\hline & & $\begin{array}{c}\text { Sample } \\
(+ \text { ve/total })\end{array}$ & $\begin{array}{c}\text { Virus titer } \\
\text { EID }_{50} / \\
\log _{10}\end{array}$ & $\begin{array}{l}\text { Viral re- } \\
\text { duction } \\
\log _{10}\end{array}$ & & CT & $\begin{array}{c}\text { Conc. } \\
\text { (cop- } \\
\text { ies/140ml) }\end{array}$ & \\
\hline $\begin{array}{l}\text { rFP-Al-H5 (Scot- } \\
\text { land) }\end{array}$ & $26.7 \%$ & $13 / 15$ & 8 & 0.5 & $12 / 15$ & 27.10 & $1.3 \times 10^{6}$ & $+\mathrm{ve}$ \\
\hline rFP-AI-H5 (Ireland) & $40 \%$ & $12 / 15$ & 7.8 & 0.7 & $12 / 15$ & 27.26 & $1.338 \times 10^{6}$ & $+\mathrm{ve}$ \\
\hline rHVT-H5 & $93.3 \%$ & $1 / 15$ & 2.5 & 6 & $0 / 15$ & 32.75 & $2.675 \times 10^{4}$ & -ve \\
\hline k rND-Al & $86.7 \%$ & $6 / 15$ & 5 & 3.5 & $3 / 15$ & 28.69 & $4.001 \times 10^{5}$ & -ve \\
\hline k rBuc-Al+ND & $93.3 \%$ & $4 / 15$ & 3.7 & 4.8 & $1 / 15$ & 33.02 & $1.586 \times 10^{4}$ & -ve \\
\hline k R H5N1 / Egy & $100 \%$ & $1 / 15$ & 2.5 & 6 & $0 / 15$ & 33.33 & $1.22 \times 10^{4}$ & -ve \\
\hline k H5N2 & $93.3 \%$ & $2 / 15$ & 4 & 4.5 & $0 / 15$ & 32.24 & $3.964 \times 10^{4}$ & -ve \\
\hline $\mathrm{k} A \mathrm{l}+\mathrm{ND}$ & $86.7 \%$ & $3 / 15$ & 4.5 & 4 & $1 / 15$ & 30.75 & $1.108 \times 10^{5}$ & -ve \\
\hline Control & 0 & $5 / 5$ & 8.5 & 0 & $5 / 5$ & 26.48 & $1.6 \times 10^{6}$ & $+v e$ \\
\hline
\end{tabular}

\section{DISCUSSION}

The ongoing H5N1 HPAl virus epidemic in poultry in Egypt underlines difficulties in controlling and eradicated in this infection vaccination was introduced in Egypt as a common tool to prevent or reduce loss due to $\mathrm{Al}$ infection. Although the efforts in controlling the infection, the virus is still circulating causing economic losses to the poultry sector with direct and indirect pressure on livehood of people. A variety of vaccines are used to control the disease in chicken as inactivated whole Al virus oil emulsion vaccines. Other types of live and inactivated vectored vaccines have been developed for Al vaccination protocol as fowl pox (Beard et al (1991), baculovirus (Yang et al 2007), herpes (Gardin et al 2016) or Newcastle dis. Virus (Ge et al 2007).

In the present study, not all tested Al vaccines induced substantial $\mathrm{HI}$ antibody responses in vaccinated chicken (table 3 ). The inactivated whole virus mono Al vaccines either K R H5N1 / Egy or K H5N2 induced a homogenous $\mathrm{HI}$ antibody response against the homologous antigens allover period of observation (10 WPV), while, the live vector recombinant vaccine (rHVT-H5) was lower immunogenic in a $\mathrm{HI}$ antibody response against the corresponding virus (Tian et al 2005). Also, the inactivated recombinant vaccines ( $\mathrm{rND}-\mathrm{Al}$ and $\mathrm{k}$ rBuc-Al+ND) showed increase in antibody response mimic the inactivated vaccines. In endemic H5 HPAl virus countries such as Egypt, the fre- quent antigenic drift of AIV requires continuous and strict vaccine evaluation using challenge test to keep up the vaccine efficacy (Suarez, 2010). In the present study, the efficacy of different recombinant $\mathrm{Al}$ vaccines against both clade 2.2.1.2 (classical group) and 2.2.1.1 (variant group) of H5N1 HPAl viruses in comparison with the inactivated oil emulsion Al vaccines. Representatives of dominant clades of the Al viruses were selected based on the year of isolation, the pathogenicity and genetic characterization. The two challenge virus were A/Ch/Egypt/1709-6/2008 (clade 2.2.1.1) representative as variant strain and $\mathrm{A} / \mathrm{Ch} / \mathrm{Egypt} /$ Qal-3/2016 (clade 2.2.1.2) which representative as classical strain. The single-shot vaccination scheme of the tested recombinant and oil emulsion Al vaccines was done. The vaccine efficacy of the tested vaccines depend on that they provide complete protection from morbidity, mortality and virus shedding against a lethal dose of challenge viruses (Kim et al 2008). The protection of chicken was evaluated by prevention of respiratory or general clinical signs (morbidity), deaths (mortality) and virus shedding from tracheal during observation period after challenge (Xie and Stone, 1990).

Al virus is usually isolated and detected by inoculation of swabs from tracheal or cloacal pathways of infected birds into chorioallantoic sac of embryonating chicken egg (Nayak et al 2009). rRT-PCR is a relatively new technology that has been used for Al virus detection since the early 2000s (Pushko et al 2017). In this study, the viral 
shedding was detected from tracheal swabs of the challenged birds by both viruses reisolation in ECE and rRT-PCR. All the chickens immunized with two types of rFP-Al-H5 Scotland and Ireland were not protected against both the classical ( 20 \& 33.3\%, respectively) and variant (26 \& 40\%, respectively) challenge viruses (Tables $4 \& 5$ ). These results are matching with Swayne et al (2000) who reported the effectiveness of recombinant hatchery vaccine using rFP-Al-H5 due to prior exposure or vaccination of breeder with fowl pox virus alone leading to vaccination failure. Also, from Tables (4 \& 5) the present study showed that there was greater viral shedding of HPAl challenge viruses (classical \& variant strains) from tracheal swabs in case of chicken vaccinated with two types of rFP$\mathrm{Al}-\mathrm{H} 5$ when estimated either by viral reisolation in ECE or rRT-PCR methods. Also, the tracheal swabs from the some birds were positive for viral shedding of the two challenge viruses when examined by rRT-PCR. These data are consistent with the studies carried out by Lee and Suarez, (2004) who found that there was a correlation between haemagglutinin sequence similarity and the ability of vaccine to reduce the tracheal titers of challenge virus.

The $\mathrm{k}$ rBuc-Al+ND vaccine the protection \% was $93.3 \%$ against the two types of challenge virus as shown in Tables (4 \& 5). Also, it was observed that there was a great reduction in viral shedding from the vaccinated birds with a ratio of $3 \log _{10}$ and $4.8 \log _{10}$ after challenge with variant and classical challenge viruses, respectively when detected with egg inoculation system (Tables 6 \& 7). The tracheal swabs taken from vaccinated-challenged birds against two challenge viruses were negative when examined by rRT-PCR. Previous studies showed that full protection was occur following vaccination of chickens with one shot of $k$ rBuc$\mathrm{Al}+\mathrm{ND}$ vaccine against challenge with HPAIVs (Beato, et al 2013). Another study by Crawford et al (1999) demonstrated protection of the vaccinated bird with bacullovirus based vaccines against heterologous challenge viruses. Also, Tables (4 \& 5) gives a simple overview of the protection results collected through challenge tests conducted with rHVT-H5 vaccine against classical and variant HPAl infection. The protection \% of chicken vaccinated with one shot of rHVT-H5 at one day old and challenged at 4 WPV was $93.3 \%$ against HPAIV strains of different clades of $\mathrm{H} 5 \mathrm{~N} 1$ and different doses of challenge viruses. A reduction of virus shedding, both by ECE virus reisolation and rRT-PCR, was done following challenge by classi- cal and variant viruses. It was showed that from Tables $(6 \& 7)$ there was a reduction in viral shedding within the acceptable ranges (ECE and rRTPCR) against classical and variant viruses, this agreed with Kilany et al (2014) who said that the higher homology between the $\mathrm{H} 5$ gene in the commercially used Al vaccine induced in the rHVT$\mathrm{H} 5$ and the circulated viruses, the higher protection afforded from this vaccines. The studies indicated that rHVT-H5 has no interference with MDA and therefore low effect in level of clinical protection. The rHVT-H5 vaccine has also been studied in short cycle birds (broiler) and its efficacy confirmed with a protection range of $90-100 \%$ depending on the presence or absence of MDA (Ranw et al (2012) also showed 95\% clinical protection in broiler birds vaccinated with rHVT-H5 at one day old. Kilany et al (2014) observed that single hatchery vaccination with rHVT-H5 vaccine confers protection against HPAI H5 in commercial layer chickens at least during rearing period (19 wks).

However, the $\mathrm{k}$ rND-Al vaccine provided $86.7 \%$ protection for both challenge viruses (variant \& classical) as shown in Tables (4 \& 5). Reduction of virus shedding detection, both by two methods either virus reisolation ECE as well as rRT-PCR shown in Tables ( $6 \& 7$ ). It was observed that the vaccine was reduce the viral shedding in vaccinated birds which challenged with variant HPAI virus with a range of $2.2 \mathrm{EID}_{50}$ and $4.3 \times 10^{5}$ RNA copies when compared with the control birds. However, the reduction in the viral shedding in vaccinated chicken challenged with classical HPAI virus was ranged from $3.5 \mathrm{EID}_{50}$ and $4 \times 10^{5}$ RNA copies. In studies by Nayak et al (2009), recombinant NDV viruses expressing the HA gene of H5N1 AIV that were constructed using the LaSota strain induced significant $\mathrm{HI}$ antibody responses against NDV and H5N1 AIV and provided complete immune protection from challenges with NDV as well as from lethal challenges with both homologous and heterologous H5N1 AIV.

Meanwhile, the protection \% of chicken vaccinated with one dose of K R H5N1 / Egy, K H5N2 and $\mathrm{K} \mathrm{H} 5 \mathrm{~N} 2$ + ND vaccines were 100\%, 92.9\% and $85.7 \%$ respectively (table 4 ) after challenge with HPAI variant strain, but from the data shown in Table (5), it is observed that $\mathrm{K} \mathrm{R} \mathrm{H5N1}$ / Egy, K $\mathrm{H} 5 \mathrm{~N} 2$ and $\mathrm{K}$ H5N2 + ND vaccines could protect the chicken against classical strain of HPAI with $100 \%, 93.3 \%$ and $86.7 \%$, respectively. Reduction of virus shedding detection, both by two methods either virus reisolation ECE as well as $\mathrm{rRT}$-PCR was always done 2 days following challenge either 

induce immune response in chicken

by classical and variant HPAl strains (Tables 6 \& 7). It was observed that the $\mathrm{K} \mathrm{R} \mathrm{H5N1} \mathrm{/} \mathrm{Egy,} \mathrm{K}$ $\mathrm{H} 5 \mathrm{~N} 2$ and $\mathrm{K} \mathrm{H} 5 \mathrm{~N} 2+\mathrm{ND}$ vaccines were reduce the viral shedding in vaccinated birds which challenged with variant HPAI virus with a range of 3.5$2.5 \mathrm{EID}_{50}$ and $1.2 \times 10^{3}$ RNA copies when compared with the control birds. However, the reduction in the viral shedding in vaccinated chicken challenged with classical HPAI virus was ranged from 4-6 EID 50 and $1.2 \times 10^{3}$ RNA copies.

The results demonstrated that inactivated vaccines (either whole virus or recombinant) and live rHVT-H5 vaccines induced more effective protection against both classical and variant HPAIV challenge viruses than live rFP-Al-H5 vaccines. Some avian viruses have been used as viral vectors to develop recombinant $\mathrm{Al}$ vaccines as rFPV (Swayne et al 2000) or ND (Nayak et al 2009) expressing AIV H5 gene.

But, it was observed that the live rHVT-Al vaccine induced more effective and prolonged protection against HPAl challenge viruses than the live rFP-Al-H5 vaccines and this agreed with ( $\mathbf{L i}$ et al 2011) who found that chicken vaccinated with rHVT vaccine expressing AlH5 HA were protected against $\mathrm{Al}$ infection. One of the concerns of vaccination against $\mathrm{Al}$ is that single dose of current vaccines do not produce sufficient immunity to completely prevent $\mathrm{Al}$ infection and subsequent virus transmission. Although, our study demonstrated that vaccination with inactivated Al vaccines (either whole virus or recombinant) able to reduce the spread of AIV within flock (Swayne, 2015) and reduce uniform protection from the clinical signs or death after challenge by different strains of HPAl viruses.

Finally, the data from this study cleared that the using of killed $\mathrm{Al}$ vaccines induced higher $\mathrm{HI}$ antibody titer, protection and reduction in viral shedding of challenge virus more than the live vector recombinant vaccines. Also, the rHVT-Al vaccine is more effective than other live recombinant $\mathrm{Al}$ vaccines due to HVT behavior in induction of prolonged immune response (Kapczynski et al 2012). Also, the usage of killed recombinant $\mathrm{Al}$ vaccines can be more effective for allowing differentiation of infected from vaccinated birds (DIVA) (Lozano-Dubernard et al 2010) beside their ability for induction of good immunity and reducing high level of viral shedding (Cui et al 2013). On the other hand, our study illustrated that all inactivated Al vaccines (whole virus or recombinant) and rHVT-Al vaccines are able to produce high protective immunity with good reduction in viral shedding against both classical and variant strains of HPAI virus a proximately with the same levels. These agreed with the Kim et al (2008) who said that the good manufacturing vaccines can protect chicken against different strains of AIV. So, there are other parameters which increase vaccine efficacy as good manufacturing procedures, proper adjuvant system, biosafety and biosecurity facilities and route of immunization (OIE, 2017).

However, all these $\mathrm{Al}$ vaccines have advantages and disadvantages, a spectrum of effective vaccines is highly desirable and the licensing of available vaccines should be promoted to supplement and expand current intervention strategies against avian influenza consistent under different epidemiological situations.

\section{REFERENCES}

Beard C.W., Schnitzlein, W.M. and Tripathy, D.N. 1991. Protection of chickens against highly pathogenic avian influenza virus (H5N2) by recombinant fowl pox viruses. Avian Dis., 35, 356-359.

Beato, M.S., Realpe-Quintero, M., Bonfante, F., Mancin, M., Ormelli, S., Calogero, T., Gonzalez-Hdez, C. and Capua, I. 2013. Cross-clade protection against H5N1 HPAI strains recently isolated from commercial poultry in Egypt with a single dose of a baculovirus based vaccine. Vaccine. 31, 5075-5081.

Crawford, J., Wilkinson, B., Vosnesensky, A., Smith, G. and Garcia, M. 1999. Baculovirusderived hemagglutinin vaccines protect against lethal influenza infections by avian $\mathrm{H} 5$ and $\mathrm{H} 7$ subtypes. Vaccine, 17, 2265-2274.

Cui, H., Gao, H., Cui, X., Zhao, Y., Shi, X., Li, Q., Yan, S., Gao, M., Wang, M., Liu, C. and Wang, Y. 2013. A virulent Marek's disease virus type 1 strain 814 vectored vaccine expressing avian influenza (Al) virus $\mathrm{H} 5$ haemagglutinin induced better protection than Turkey herpesvirus vectored Al vaccine. PLOS one 8: e53340.

Das, A., Spackman, E., Pantin-Jackwood, M.J. and Suarez, D.L. 2009. Removal of real-time reverse transcription polymerase chain reaction (RT-PCR) inhibitors associated with cloacal swab samples and tissues for improved diagnosis of Avian influenza virus by RT-PCR. J. Vet. Diagn. Invest. 21, 771-778.

DiNapoli, J.M., Nayak, B., Yang, L. and Finneyfrock, B.W. 2010. Newcastle disease virus-vectored vaccines expressing the he- 
magglutinin or neuraminidase protein of H5N1 highly pathohenic avian influenza virus protect against virus challenge in monkeys. J. Virol. 84, 1489 -1503.

Ellebedy, A.H. and Webby, R.J. 2009. Influenza vaccines. Vaccine, 27, D65-68.

Gao, W., Soloff, A.C., Lu, X., Montecalvo, A. and Nguyen, D.C. 2006. Protection of mice and poultry from lethal H5N1 avian influenza virus through adenovirus-based immunization. J. Virol 80, 1959-1964.

Gardin, Y., Palya, V., Dorsey, K.M., El-Attrache, J., Bonfante, F., de Wit, S., Kapczynski, D., Kilany, W.H., Rauw, F., Steensels, M. and Soejoedono, R.D. 2016. Experimental and field results regarding immunity induced by a recombinant turkey herpesvirus $\mathrm{H} 5$ vector vaccine against $\mathrm{H} 5 \mathrm{~N} 1$ and other $\mathrm{H} 5$ highly pathogenic avian influenza virus challenges. Avian Diseases, 60, 232-237.

Ge, J., Deng, G., Wen, Z., Tian, G. and Wang, Y. 2007. Newcastle disease virus based live attenuated vaccine completely protects chickens and mice from lethal challenge of homologous and heterologous $\mathrm{H} 5 \mathrm{~N} 1$ avian influenza viruses. J. Virol., 81, 150-158.

Kapczynski, D.R., Moraes, M., Jackwood, M.W. and Moore Dorsey, K. 2012. Vaccination of SPF turkeys with a recombinant HVT expressing the HA from H5N1 highly pathogenic avian influenza protects against lethal challenge. In: Proc. Of the American Association of Avian Pathologists Meeting, SanDiego, CA. Study code 12632.

Kilany, W.H., Dauphin, G., Selim, A., Tripodi, A., Samy, M., Sobhy, H., Von Dobschuetz, S., Safwat, M., Saad, M., Erfan, A., Hassan, M., Lubroth, J. and Jobre, Y. 2014. Protection conferred by recombinant turkey herpes-virus avian influenza (rHVT-H5) vaccine in the rearing period in two commercial layer chicken breeds in Egypt. Avian Pathol. 43, 514-523.

Kim, J.K., Seiler, P., Forrest, H.L., Khalenkov, A.M., Franks, J., Kumar, M., Karesh, W.B., Gilbert, M., Sodnomdarjaa, R., Douangngeun, B., Govorkova, E.A. and Webster, R.G. 2008. Pathogenicity and vaccine efficacy of different clades of Asian H5N1 avian influenza A viruses in domestic ducks. J. Virol., 82, 11374-11382.

Kreijtz, J.H., Suezer, Y., van Amerongen, G., de Mutsert, G. and Schnierle, B.S. 2007. Recombinant modified vaccinia virus Ankarabased vaccine induces protective immunity in mice against infection with influenza virus H5N1. J. Infect. Dis. 195, 1598-1606.

Lee, C.W. and Suarez, D.L. 2004. Application of real-time RT-PCR for the quantification and competitive replication study of $\mathrm{H} 5$ and $\mathrm{H} 7$ subtype avian influenza virus. J. Virol. Methods, 119, 151-158.

Li, Y., Reddy, K., Reid, S.M., Cox, W.J. and Brown, I.H. 2011. Recombinant herpesvirus of turkeys as a vector-based vaccine against highly pathogenic $\mathrm{H} 7 \mathrm{~N} 1$ avian influenza and Marek's disease. Vaccine 29, 8257-8266.

Lozano-Dubernard, B., Soto-Priante, E., SarfatiMizrahi, D., Castro-Peralta, F., FloresCastro, R.; Loza-Rubio E. and GayGutiěrrez, M. 2010. protection and differentiation of infected from vaccinated animals by an inactivated recombinant Newcastle disease virus/avian influenza H5 vaccine. Avian Dis., 54, 242-245.

Lupiani, B. and Reddy, S.M. 2009. The history of avian influenza. Comp Immunol Microbiol Infect. Dis., 32, 311-323.

Mueller, S.N., Langley, W.A., Carnero, E., Garcia-Sastre, A. and Ahmed, R. 2010. Immunization with live-attenuated influenza viruses expressing altered NS1 proteins results in potent and protective memory CD8+T cells responses. J. Virol. 84, 1847-1855.

Munster, V.J. and Fouchier, R.A. 2009. Avian influenza virus: of virus and bird ecology. Vaccine 27, 6340-6344.

Nayak, B., Rout, S.N., Kumar, S., Khalil, M.S. and Fouda, M.M. 2009. Immunization of chickens with Newcastle disease virus expressing $\mathrm{H} 5$ hemagglutinin protects against highly pathogenic H5N1 avian influenza viruses. PLoS One 4, e6509.

OIE Office International des Epizoties 2017. Chapter 2.3.4. In: Manual of diagnostic tests and vaccines for terrestrial animals. Version adopted by the World assembly of Delegates of the OIE in May 2015.

Pushko, P., Tretyakovaa, I., Hidajata, R., Zsakb, A., Chrzastek, K., Tumpey, T.M., Kapczynski, D.R. 2017. Virus-like particles displaying $\mathrm{H} 5, \mathrm{H} 7, \mathrm{H} 9$ hemagglutinins and $\mathrm{N} 1$ neuraminidase elicit protective immunity to heterologous avian influenza viruses in chickens. Virology, 501, 176-182.

Rao, S., Kong, W.P., Wei, C.J., Yang, Z.Y. and Nason, M. 2008. Multivalent HA DNA vaccination protects against highly pathogenic H5N1 

induce immune response in chicken

avian influenza infection in chickens and mice. PLoS One 3, e2432.

Rauw, F., Palya, V., Tatar-kis, T., Dorsy, M.K., van den Berg, T., Lambrecht, B. and Gardin, Y. 2012. Lack of interference between two recombinant HVT vaccines expressing the H5 protein of influenza or the F protein of Newcastle disease administered simultaneously to dayold chicks and efficacy against challenges performed at 4 or 8 w eek $s$ of age. In Brown, I.; Swayne, D.E. and Kuiken, T. (Eds.), Proceedings of the VIIlth International Symposium on Avian Influenza 94 p.. London, UK

Robert, G., Webster, A.S., Thomas, M., Braciale, J. and Lamb A. 2013. Textbook of Influenza, $2^{\text {nd }}$ Ed., 520.

Suarez, D.L. 2010. Avian influenza: our current understanding. Anim Health Res Rev 11:19-33.

Swayne, D.E. 2003. Vaccines for list A poultry diseases; emphasis on avian influenza. Dev. Biol. (Basel), 114, 201-212.

Swayne, D.E., Suarez, D.L., Spackman, E., Jadhao, S., Dauphin, G., Kim-Torchetti, M., McGrane, J., Weaver, J., Daniels, P., Wong, F., Selleck, P., Wiyono, A., Indriani, R., Yupiana, Y., Sawitri Siregar, E., Prajitno, T., Smith, D., and Fouchier, R. 2015. Antibody titer has positive predictive value for vaccine protection against challenge with natural antigenic-drift variants of $\mathrm{H} 5 \mathrm{~N} 1$ high-pathogenicity avian influenza viruses from Indonesia. Journal of Virology, 89, 3746-3762.

Swayne, D.E., Garcia, M., Beck, J.R., Kinney, N. and Suarez, D.L. 2000. Protection against diverse highly pathogenic $\mathrm{H} 5$ avian influenza viruses in chickens immunized with a recombinant fowl pox vaccine containing an $\mathrm{H} 5$ avian influenza hemagglutinin gene insert. Vaccine, 18, 1088-1095.
Swayne, D.E., Senne, D.A. and Beard, C.W. 1998. Avian Influenza, in a laboratory manual for the isolation and identification of avian pathogens, $4^{\text {th }}$ Ed. Kennett Square, PA: American Association of Avian Pathologists.

Tian, G., Zhang, S., Li, Y., Bu, Z., Liu, P., Zhou, J., Li, C., Shi, J., Yu, K. and Chen, H. 2005. Protective efficacy in chickens, geese and ducks of an H5N1-inactivated vaccine developed by reverse genetics 6 . Virology, 341, 153-162.

Toro, H., Tang, D.C., Suarez, D.L., Zhang, J. and Shi, Z. 2008. Protection of chickens against avian influenza with non-replicating adenovirusvectored vaccine. Vaccine, 26, 2640-2646.

Van Oirschot, J.T. 2001. Present and future of veterinary viral vaccinology: a review. Vet. Q., 23, 100-108.

Wu, Q., Fang, L., Wu, X., Li, B., Luo, R. and Yu, Z. 2009. A pseudotype baculovirus-mediated vaccine confers protective immunity against lethal challenge with $\mathrm{H} 5 \mathrm{~N} 1$ avian influenza virus in mice and chickens. Mol. Immunol., 46, 2210-2217.

Xie, Z.X. and Stone, H.D. 1990. Immune response to oil emulsion vaccines with a single or mixed antigens of Newcastle, avian influenza and infectious bronchitis. Avian diseases, 34, 154162.

Yang, D.G., Chung, Y.C., Lai, Y.K., Lai, C.W. and Liu, H.J. 2007. Avian influenza virus hemagglutinin display on baculovirus envelope; cytoplasmic domain affects virus properties and vaccine potential. Mol. Ther., 15, 989-996.

Yen, H.L. and Webster, R.G. 2009. Pandemic influenza as a current threat. Curr Top Microbiol. Immunol., 333, 3-24. 